\title{
Pregledni rad
}

Primljen: 6. svibnja 2021.

Prihvaćen: 15. rujna 2021.

\section{Iva Batur, asist.}

Filozofski fakultet Sveučilišta u Zagrebu

Odsjek za pedagogiju

idebelja@ffzg.hr

https://orcid.org/0000-0003-3622-6338

\section{Amanda Glavaš, asist.}

Filozofski fakultet Sveučilišta Josipa Jurja Strossmayera u Osijeku

Katedra za zajedničke sadržaje

aglavas@ffos.hr

https://orcid.org/0000-0003-3239-7949

\section{DJECA S POSEBNIM POTREBAMA U VERTIKALI HRVATSKOG ODGOJNO-OBRAZOVNOG SUSTAVA: KOMPARATIVNA ANALIZA ZAKONSKE REGULATIVE}

Sažetak: Inkluzivni odgoj i obrazovanje prihvaća činjenicu da sva djeca imaju različite (posebne) potrebe koje je potrebno uvažavati. Preduvjet su za to zakonske regulative za odgoj i obrazovanje djece s posebnim odgojno-obrazovnim potrebama koje se kontinuirano ažuriraju u skladu sa suvremenim znanstvenim spoznajama.

Cilj je ovog istraživanja bio utvrditi razlike u zakonskom reguliranju odgoja i obrazovanja djece s posebnim odgojno-obrazovnim potrebama na vertikalnoj i/ili horizontalnoj razini. Na vertikalnoj razini uspoređuju se dva podsustava: a) rani i predškolski te b) školski - osnovnoškolski i srednjoškolski. S druge strane, na horizontalnoj razini uspoređuju se dvije podskupine: djeca i učenici $s$ teškoćama u razvoju te darovita djeca i učenici. S tom je namjerom u istraživanju provedena kvalitativna komparativna analiza primarnih izvora podataka u zakonskim aktima koji reguliraju odgoj i obrazovanje djece s posebnim potrebama u Republici Hrvatskoj.

Analizom je utvrđena bolja reguliranost školskog odgojno-obrazovnog sustava $u$ odnosu na rani i predškolski te bolja reguliranost akata koji se tiču djece $i$ učenika s teškoćama u razvoju u odnosu na darovite. Prema tome, dobiveni rezultati upućuju na potrebu reguliranja zakonskih akata prethodno navedenih sustava i skupina s ciljem zadovoljenja njihovih potreba.

Ključne riječi: darovita djeca, djeca s teškoćama, inkluzija, odgojno-obrazovni proces. 
I. Batur, A. Glavaš: Djeca s posebnim potrebama u vertikali hrvatskog ...

\section{UVOD}

Smatra se da je razvoj društva uvjetovan smanjenjem razlika u društvu, a veliku ulogu u tome ima odgoj i obrazovanje čiji uspjeh ovisi i o prilagodbi poučavanja individualnim razlikama među djecom. Prvi je korak u tome postavljanje zakonskih okvira i osmišljavanje odgojno-obrazovnih mjera koje će omogućiti provedbu inkluzije i to na svim razinama odgojno-obrazovnog sustava (Ainscow i Tweddle, 2003). Sam pojam inkluzije podrazumijeva osiguravanje mogućnosti za učenje bez obzira na posebnosti djece te primjerenu podršku u razvoju i stjecanju kompetencija, a u okviru redovitog odgoja i obrazovanja (Luketić i Karamatić Brčić, 2018). U uvodnom dijelu rada opisat će se kako se pristup djeci s teškoćama u razvoju i darovitoj djeci te njihovom odgoju i obrazovanju mijenjao tijekom povijesti.

Naime, odnos se prema djeci (i odraslima) s teškoćama u razvoju tijekom povijesti mijenjao od diskriminirajućeg prema samilosnom pa do odnosa koji promovira prava i slobodu čovjeka (Sunko, 2016). Samilosni i diskriminirajući odnosi te odnosi koji promoviraju prava i slobodu pojedinca tijekom povijesti konstituirali su se u pristupe ili modele koji se mogu podijeliti na: individualni/ medicinski/humanitarni model koji problem nalazi u pojedincu (Stubbs, 2008), socijalni model koji problem, kao i rješenje, nalazi u društvu i odgojno-obrazovnom sustavu (Booth i Ainscow, 2002; Stubbs, 2008) te model ljudskih prava (Quinn i Degener, 2002).

U pozadini je navedenih odnosa, pristupa i modela određena koncepcija ili paradigma koja se dominantno zastupa, a autori navode sljedeće paradigme: pozitivističko-funkcionalistička nasuprot emancipacijskoj paradigmi (Sunko, 2016) ili medicinsko-psihološka nasuprot post-pozitivističkoj (Cerić, 2008). Ukratko, u podlozi pozitivističko-funkcionalističke i medicinsko-psihološke paradigme jest shvaćanje djeteta kao problema, odnosno postavljanje teškoće, a ne osobe, u središte pažnje te organizacija različitih specijalnih ustanova koje će ih otkloniti ili umanjiti (Cerić, 2008). Opisima invalidnosti ili teškoće kao odstupanja od zadanih standarda, djeca s teškoćama u razvoju svrstavaju se u manje vrijedne, a samo odstupanje izgleda kao njihov problem (Igrić, 2004).

$\mathrm{S}$ druge strane, u okviru emancipacijske i post-pozitivističke paradigme razmatraju se i neki drugi čimbenici koji utječu na pojavu posebnih potreba, kao što su socijalni procesi. Drugim riječima, u obzir se uzima široki spektar barijera ili prepreka učenju i participaciji (Booth i Ainscow, 2002; Clark i sur., 2005). Navedene paradigme polaze od slobode, ostvarivanja ljudskih prava, integracije i sudjelovanje u zajednici te inkluzije kao društvene i kulturne vrijednosti (Sunko, 2016). Pomak od medicinskog prema socijalnom modelu te modelu ljudskih prava ili, drugim riječima, pomak od medicinsko-psihološke prema emancipacijskoj paradigmi ujedno znači i pomak u shvaćanjima obrazovanja, i to od obrazovanja kao ekskluzijskog procesa prema segregirajućem 
obrazovanju u posebnim ustanovama (Sunko, 2016) do integracije, a onda i inkluzije kakva je poznata i danas. Igrić (2004) navodi kako je to pomak od obrazovanja u specijalnim ustanovama do organizacije odgoja i obrazovanja u redovitom odgojno-obrazovnom sustavu, odnosno, kako Cerić (2008) ističe, pomak od dualnog $\mathrm{k}$ inkluzivnom odgojno-obrazovnom sustavu. Ono što je $\mathrm{u}$ tom pomaku izrazito pedagoški je individualizacija, tj. uvažavanje različitih individualnih potreba sve djece (učenika) bez obzira na teškoću u razvoju (Karagiannis i sur., 2000, prema Cerić, 2008).

Preciznije rečeno, sva djeca i učenici, svi pojedinci, imaju posebne potrebe i kao takve potrebno ih je uvažavati i to u procesu inkluzivnog odgoja $i$ obrazovanja.

Također, tim se shvaćanjima napuštaju uvriježene ideje o prosječnom djetetu i konfekcijskoj nastavi koja je jednima do koljena, a drugima preko glave (Vilotijević, 1999, prema Jablan i Kovačević, 2008).

Pomaci u odnosu prema djeci s teškoćama u razvoju te u paradigmama na kojima se oni temelje dovode do pomaka u shvaćanju odgoja i obrazovanja, odnosno do drugačije organizacije odgojno-obrazovnog sustava za djecu s teškoćama u razvoju. Kao što je prethodno istaknuto, pomak je to od segregirajućeg $\mathrm{k}$ inkluzivnom odgoju i obrazovanju. Stoga će u nastavku biti definirani pojmovi koji se u tom kontekstu pojavljuju, a to su: inkluzija, obrazovna inkluzija, integracija i inkluzivno obrazovanje.

Inkluzija je pojam i proces koji obuhvaća puno šire područje od područja obrazovanja, a u užem smislu podrazumijeva obrazovnu inkluziju. Drugim riječima, inkluzija u širem smislu podrazumijeva odnose na relaciji pojedinac -društvo i obrnuto te se definira kao proces kojim se osigurava da svaki pojedinac ili član društva, bez obzira na mogućnosti, iskustva i životne okolnosti, može ostvariti svoje potencijale (Cerić, 2008). Brojni autori u tom smislu ističu kako je inkluzija nešto puno više od pojma, teorije ili koncepcije, odnosno ona je pedagoško-humanistički pokret koji teži stvaranju uvjeta za optimalan razvoj svakog pojedinca u skladu s njegovim potencijalima (Pašalić-Kreso, 2003, prema Cerić, 2008), ona je pokret protiv predrasuda, diskriminacije i segregacije, pokret za toleranciju i uvažavanje različitosti (Slatina, 2003, prema Cerić, 2008), ali i još mnogo toga.

Ako se, pak, inkluzija promatra u užem smislu i to u kontekstu odgoja i obrazovanja, onda se ona odnosi na obrazovnu inkluziju (Sindik, 2013) koja je shvaćena kao strategija minimiziranja svih barijera u obrazovanju za sve učenike, a polazi od prepoznavanja razlika među učenicima (Booth i Ainscow, 2002).

Međutim, u odgoju i obrazovanju kao prijelazni oblik između segregacije djece $s$ teškoćama $u$ razvoju u posebnim ustanovama i inkluzije u redovitim odgojno-obrazovnim ustanovama najprije se pojavila integracija. Integracija je značila puko uključivanje djece s teškoćama u razvoju u redoviti sustav odgoja 
i obrazovanja, ali nije nužno podrazumijevala prilagodbu okruženja za učenje djetetu (Sindik, 2013). Drugim riječima, taj je proces podrazumijevao fizičko, no ne i socijalno uključivanje djece s teškoćama u razvoju u redoviti odgojno-obrazovni sustav (Jablan i Kovačević, 2008). Nadalje, obrazovna inkluzija, za razliku od integracije, podrazumijeva da djeca sa i bez teškoća u razvoju borave u istom okruženju za učenje, ali i da zajednički uče, igraju se i druže (Sindik, 2013). Kriteriji visokokvalitetnih inkluzivnih programa, a ti kriteriji mogu poslužiti kao kriteriji za uočavanje razlike između integracije i inkluzije, su: pristup (dostupnost aktivnosti i okruženja za učenje), participacija (pripadnost djeteta grupi i promoviranje zajedničkih aktivnosti sve djece) i podrška (profesionalni razvoj i suradnja obitelji i stručnjaka) (DEC NAEYC, 2009).

Sukladno navedenim definicijama inkluzije, inkluzivno obrazovanje promišlja se kao obrazovno okruženje koje može odgovoriti na potrebe sve djece $i$ to bez obzira na njihove međusobne razlike (Sindik, 2013). O problemima koji su vezani za integraciju i inkluziju djece s teškoćama u razvoju u redoviti odgojno-obrazovni sustav govore sljedeća provedena istraživanja:

- inkluzivna podrška djeci s teškoćama u razvoju u sustavu ranog i predškolskog odgoja i obrazovanja u smislu kadra nije dostatna, a pojam asistenta ili pomoćnika u vrtićima zakonski ne postoji (Pravobraniteljica za osobe s invaliditetom, 2019);

- u školama ne postoji kadrovska ekipiranost, odnosno stručna podrška u procesu obrazovanja i rehabilitacije je nedostatna zbog zapošljavanja neprimjerenog broja stručnih suradnika (Igrić, 2004; OECD, 2007);

- razredi imaju previše učenika, a stručnost je učitelja neodgovarajuća, stoga postoji potreba stručnog osnaživanja ustanova edukacijama djelatnika (OECD, 2007; Pravobraniteljica za osobe s invaliditetom, 2013);

- na svim razinama postoji problem uređenja institucije asistenta u nastavi i određena nedorečenost propisa u tom području (Brajša-Žganec i sur., 2014).

S druge strane, kada se govori o darovitoj djeci, ona su bila relativno zapostavljena, a u središte interesa odgojno-obrazovne politike dolaze tek zadnjih dvadesetak godina kada se brojne zemlje odlučuju na reforme kako bi identificirale darovitu djecu i prilagodile se njihovim potrebama i sposobnostima (Vican, 2018). Osim toga, javna je kritika usmjerena na tradicionalni pristup nastavi u kojem je škola prilagođena prosjeku, u kojem se zanemaruju darovita djeca, a u središtu su djeca s teškoćama u razvoju (Zirkel, 2004, prema Luketić i Karamatić Brčić, 2018), ali i u kojem su odgojno-obrazovni djelatnici nedovoljno osposobljeni za rad s darovitom djecom (Vican, 2018).

U početku 20 -ih godina 20 . stoljeća znanstvena istraživanja darovitosti vezala su se uz proučavanje djece koja su na testovima inteligencije pokazivala natprosječne sposobnosti (Terman, 1925, prema Vizek Vidović i sur., 2003). 
Pojavom suvremenijih definicija inteligencije, tj. pomakom od jednostrukih $\mathrm{k}$ višestrukima, pojavljuju se i brojne definicije darovitosti. Naime, Gardnerov model (1983, prema Vizek Vidović i sur., 2003) usmjeren je na osobine darovitih, a navodi da postoji sedam različitih specifičnih sposobnosti, talenata ili inteligencija u kojima dijete može biti darovito (logičko-matematička, lingvistička, vizualno-spacijalna, tjelesno-kinestetička, glazbena, interpersonalna i intrapersonalna). Osim toga, Sternbergov trijarhijski model (1990, prema Vizek Vidović i sur., 2003) kognitivni je model prema kojem su indikatori darovitosti vještine uspješnog rješavanja problema i usvajanja znanja (analitička, sintetička i praktična sposobnost). Prema Sternbergu (1990, prema Vizek Vidović i sur., 2003) osim u kvantitativnim razlikama, darovitost se očituje i u specifičnom načinu mentalnog funkcioniranja. Nadalje, Renzullijeva troprstenasta teorija darovitosti (1978, prema Vizek Vidović i sur., 2003) usmjerena je na postignuće. Ukratko, Renzulli (1978, prema Vizek Vidović i sur., 2003) ističe da je darovito ponašanje rezultat interakcije iznadprosječne opće i/ili specifične sposobnosti, visoke usmjerenosti na zadatak te visokog stupnja kreativnosti. Marland (1971, prema Vizek Vidović i sur., 2003) pak ističe kako su darovita djeca ona koja zbog svojih iznimnih sposobnosti u području općih intelektualnih sposobnosti, specifičnih školskih sposobnosti, kreativnih sposobnosti, sposobnosti vođenja i rukovođenja, umjetničkih sposobnosti i/ili psihomotornih sposobnosti mogu očekivati visoka postignuća. Uzimajući u obzir spomenuto, sinteza se definicija darovite djece Marland (1971) i Renzullija (1990) koristi kao definicija darovite djece u okviru zakonskih akata Republike Hrvatske za osnovnoškolsku i srednjoškolsku djecu (prema Pravilniku o osnovnoškolskom odgoju i obrazovanju darovitih učenika, 1991 i Pravilniku o srednjoškolskom obrazovanju darovitih učenika, 1993). S druge strane, za darovitu djecu uključenu u programe ranog i predškolskog odgoja i obrazovanja koristi se Korenova (1989) definicija, a darovitim djetetom naziva se dijete koje u jednom ili više područja pokazuje iznadprosječne sposobnosti (prema Državni pedagoški standard predškolskog odgoja i naobrazbe, 2008; 2010).

Nadalje, Čudina-Obradović (1991) navodi kako darovitost može biti manifestna, odnosno kad su rezultati vidljivi ili potencijalna, tj. koja se razvija uz potporu i poticaje okoline (prema Vizek Vidović i sur., 2003). Luketić i Karamatić Brčić (2018, str. 38) navode kako će se darovitost manifestirati ako su „visoke opće i specifične sposobnosti kombinirane s emotivnim i motivacijskim faktorom". Pored toga, Mönks i Mason (2000) ističu utjecaj društvenog uređenja, ekonomije, politike te kulturološke odrednice na manifestiranje, tj. ispunjenje darovitosti. Razvoj darovitosti dinamičan je proces (Cvetković-Lay, 2010) vezan uz interakciju djeteta i okolinskih uvjeta pri čemu važnu ulogu u identifikaciji, praćenju, poticanju, podršci i radu s darovitom djecom ima niz vanjskih čimbenika poput obitelji, (pred)školskog okruženja, odgojno-obrazovnih dionika, društvene sredine, Vlade i važećih propisa itd. Dakle, kako 
bi se stvorili uvjeti učenja i poučavanja u okviru odgojno-obrazovnog sustava prvenstveno je potrebno, u skladu sa suvremenim spoznajama, regulirati zakonske akte. Ipak, samo formalno uključivanje nije dovoljno, nego je potrebno i pedagoški promišljati o darovitoj djeci i učenicima. Rad s darovitom djecom i učenicima poseban je izazov svim odgojno-obrazovnim djelatnicima te je potrebno, i u tom smislu, zakonskim regulativama pružiti podršku i smjernice svima uključenima u rad s njima.

Neke od najsuvremenijih znanstveno-istraživačkih tema o darovitoj djeci indikatori su darovite djece do predškolske dobi, fenomen pažnje kod darovite djece te mentalno zdravlje i psihološka dobrobit darovite djece (Vican, 2018). Brojni istraživači, što je važno spomenuti, ukazuju na roditelje kao glavne $i$ prve sudionike u otkrivanju i prepoznavanju potencijalne darovitosti djece. Njihova uključenost u cjelokupni proces prepoznavanja i praćenja razvoja djeteta te stvaranje poticajne okoline od iznimne je važnosti za dijete (CvetkovićLay, 2010). Slično, Bloomovo je istraživanje (1982, prema Sekulić-Majurec, 1995) pokazalo da je za očitovanje darovitosti značajna i spremnost roditelja da prepoznaju darovitost jer se pretpostavlja da će roditelji nastojati poticati njezin daljnji razvoj. Također, Koren (1989) napominje i da se kod djece do predškolske dobi provodi samo proces prepoznavanja i praćenja darovitosti. Sljedeća instanca u otkrivanju darovitosti djeteta predškolske su ustanove, a poseban značaj imaju odgajatelji koji sustavno prate razvoj sposobnosti djece te planski provode odgoj i stvaraju uvjete za razvoj dječjih sposobnosti (Rajović, 2009).

Tao i Shi (2018) upozoravaju da je deficit pažnje u darovite djece vrlo često odgovor na neodgovarajući način poučavanja, npr. ako je riječ o njima nezanimljivom sadržaju ili obradi sadržaja na njima neprilagođenoj razini. U sredinama u kojima se potrebe darovitih učenika zapostavljaju, odnosno u kojima postoji nerazumijevanje okoline i destimulirajući odnos prema darovitima, često se događa da daroviti učenici postanu učenici s rizičnim ponašanjem (Zloković, 2016, prema Vican, 2018). Iako daroviti učenici potencijalno posjeduju iznimne sposobnosti, ostvarivanje očekivanja i akademskih postignuća te odrastanje s darovitošću može biti i otežavajući čimbenik za dobrobit djeteta (Luketić i Karamatić Brčić, 2018). Također, daroviti učenici mogu ostvarivati loše rezultate u određenim predmetima, a nerijetko imaju problema u socijalizaciji s vršnjacima (Delisle, 1999). Posljedično, zbog tog odbijanja češće se odlučuju na osamljivanje prilikom učenja (French i Shore, 2008), a ponekad i namjerno podbacuju (Delisle, 1999). Osim toga, neprihvaćanje može rezultirati povlačenjem pa i razvojem delinkventnog ponašanja (Vrkić Dimić i Buterin Mičić, 2018). Njihov socijalni i emocionalni razvoj može zaostajati za intelektualnim te se mogu izdvajati nametljivim ponašanjem, remećenjem rada i narušavanjem discipline suprotstavljanjem, negodovanjem i sl., privlačeći tako pozornost na sebe i svoje potrebe (Winerbrenner, 2001). Iz tog je razloga vrlo bitno u odgoju 
i obrazovanju darovitih učenika usredotočiti se, osim na kognitivno-akademske, i na osobno-socijalne potrebe (Milgram, 1991).

Navodeći probleme vezane za odgoj i obrazovanje djece s posebnim odgojno-obrazovnim potrebama, autori se poglavito pozivaju na neusklađenost ili jaz između zakonske regulative i praktične primjene dotičući se samih zakonskih akata i njihove kvalitete u manjoj mjeri. Stoga je na temelju svega navedenog definiran cilj istraživanja. Preciznije rečeno, cilj je istraživanja utvrditi razlike u zakonskom reguliranju odgoja i obrazovanja djece i učenika s posebnim odgojno-obrazovnim potrebama i to na dvije razine:

- vertikalna - usporedba dva podsustava odgoja i obrazovanja

- rani i predškolski

- školski: osnovnoškolski i srednjoškolski

- horizontalna - usporedba dvije podskupine djece i učenika s posebnim odgojno-obrazovnim potrebama

- djeca i učenici s teškoćama u razvoju

- darovita djeca i učenici.

Kako bi se pobliže odredio cilj istraživanja, postavljena su sljedeća istraživačka pitanja:

1. Jesu li regulirana prava djece i učenika s teškoćama u razvoju te darovite djece i učenika na pomoćnika, odnosno mentora, u odgojnoobrazovnom procesu?

2. Postoji li razlika u reguliranju broja djece/učenika u razrednom odjelu/ odgojno-obrazovnoj skupini između darovite djece i učenika te djece i učenika s teškoćama u razvoju?

3. Je li rad s darovitom djecom i učenicima te djecom i učenicima s teškoćama u razvoju koja su integrirana u redovne razredne odjele/odgojno-obrazovne skupine poseban uvjet kolektivnog ugovora za ostvarivanje dodatka na osnovnu plaću?

4. Koliko su se često mijenjali zakonski akti i podakti vezani uz odgoj i obrazovanje darovite djece i učenika te djece i učenika s teškoćama u razvoju?

\section{METODOLOGIJA}

Istraživanje je provedeno kvalitativnom komparativnom analizom primarnih izvora podataka, odnosno zakonskih akata koji reguliraju odgoj i obrazovanje djece s posebnim odgojno-obrazovnim potrebama u Republici Hrvatskoj, a to su:

- Državni pedagoški standard predškolskog odgoja i naobrazbe (2008; 2010);

- Zakon o predškolskom odgoju i obrazovanju (1997; 2007; 2013; 2019); 
- Pravilnik o posebnim uvjetima i mjerilima ostvarivanja programa predškolskog odgoja (1997);

- Pravilnik o obrascima i sadržaju pedagoške dokumentacije i evidencije o djeci u dječjem vrtiću (2001);

- Državni pedagoški standard osnovnoškolskog sustava odgoja i obrazovanja $(2008 ; 2010)$;

- Državni pedagoški standard srednjoškolskog sustava odgoja i obrazovanja $(2008 ; 2010)$;

- Pravilnik o osnovnoškolskom odgoju i obrazovanju darovitih učenika (1991);

- Pravilnik o srednjoškolskom obrazovanju darovitih učenika (1993);

- Pravilnik o osnovnoškolskom i srednjoškolskom odgoju i obrazovanju učenika s teškoćama u razvoju (2015);

- Pravilnik o broju učenika u redovitom i kombiniranom razrednom odjelu i odgojno-obrazovnoj skupini u osnovnoj školi (2009; 2010);

- Pravilnik o pomoćnicima u nastavi i stručnim komunikacijskim posrednicima $(2018 ; 2019 ; 2020)$;

- Zakon o odgoju i u obrazovanju u osnovnoj i srednjoj školi (2008; 2009; 2010; 2011; 2012; 2013; 2014; 2017; 2018; 2019; 2020);

- Kolektivni ugovor za zaposlenike u srednjoškolskim ustanovama (2018);

- Kolektivni ugovor za zaposlenike u osnovnoškolskim ustanovama (2018);

- Kolektivni ugovor za zaposlene u predškolskim ustanovama grada Zagreba (2015);

- Kolektivni ugovor za zaposlene u Dječjem vrtiću Rijeka (2017);

- Kolektivni ugovor za djelatnost predškolskog odgoja i obrazovanja za radnike zaposlene u Dječjem vrtiću «Maslačak» Đurđevac (2017);

- Kolektivni ugovor za radnike u Dječjem vrtiću Radost i Dječjem vrtiću Sunce (2018);

- Pravilnik o sadržaju i trajanju programa predškole (2014).

Analiza dokumenata, a u skladu s postavljenim istraživačkim pitanjima, bila je usmjerena na sljedeće kriterije usporedbe:

- ostvarivanje prava na pomoćnika ili mentora u nastavi/odgojnoobrazovnom procesu;

- regulacija broja djece/učenika u razrednom odjelu/odgojno-obrazovnoj skupini ako je uključeno dijete/učenik s posebnim odgojno-obrazovnim potrebama;

- $\quad$ rad s djecom s posebnim odgojno-obrazovnim potrebama koja su integrirana u redovne razredne odjele/odgojno-obrazovne skupine kao poseban uvjet za ostvarivanje dodatka na osnovnu plaću;

- suvremenost zakonskih akata i podataka. 


\section{REZULTATI I RASPRAVA}

Kvalitativna komparativna analiza dva podsustava odgoja i obrazovanja te dvije podskupine djece i učenika s posebnim odgojno-obrazovnim potrebama opisana je u tablici 1 .

Tablica 1. Komparativna analiza zakonskih akata

\begin{tabular}{|c|c|c|c|c|c|c|}
\hline & \multicolumn{3}{|c|}{$\begin{array}{l}\text { DJECA I UČENICI S TEŠKOĆAMA } \\
\text { U RAZVOJU }\end{array}$} & \multicolumn{3}{|c|}{ DAROVITA DJECA I UČENICI } \\
\hline & Dječji vrtić & $\begin{array}{c}\text { Osnovna } \\
\text { škola }\end{array}$ & $\begin{array}{l}\text { Srednja } \\
\text { škola }\end{array}$ & Dječji vrtić & $\begin{array}{c}\text { Osnovna } \\
\text { škola }\end{array}$ & $\begin{array}{l}\text { Srednja } \\
\text { škola }\end{array}$ \\
\hline $\begin{array}{l}\text { Pomoćnici/ } \\
\text { mentori } \\
\text { (IP.1) }\end{array}$ & Djelomično & $\mathrm{Da}$ & $\mathrm{Da}$ & $\mathrm{Ne}$ & $\mathrm{Ne}$ & $\mathrm{Ne}$ \\
\hline $\begin{array}{c}\text { Reguliranje } \\
\text { broja djece } \\
\text { (IP.2) }\end{array}$ & $\mathrm{Da}$ & $\mathrm{Da}$ & Djelomično & $\mathrm{Ne}$ & Djelomično & Djelomično \\
\hline $\begin{array}{l}\text { Dodatak na } \\
\text { plaću (IP.3) }\end{array}$ & $\begin{array}{l}\text { Nedosljedno } \\
\text { (ovisno o } \\
\text { pojedinom } \\
\text { kolektivnom } \\
\text { ugovoru) }\end{array}$ & $\mathrm{Da}$ & $\mathrm{Da}$ & $\begin{array}{l}\text { Nedosljedno } \\
\text { (ovisno o } \\
\text { pojedinom } \\
\text { kolektivnom } \\
\text { ugovoru) }\end{array}$ & $\mathrm{Ne}$ & $\mathrm{Ne}$ \\
\hline $\begin{array}{c}\text { Ažuriranje } \\
\text { zakonskih } \\
\text { akata } \\
\text { (IP.4) }\end{array}$ & $\mathrm{Ne}$ & $\mathrm{Da}$ & Djelomično & $\mathrm{Ne}$ & $\mathrm{Ne}$ & $\mathrm{Ne}$ \\
\hline
\end{tabular}

U nastavku će se rada svaki kriterij naveden u tablici 1. pobliže opisati.

\section{IP.1 - POMOĆNICI/MENTORI U NASTAVI I ODGOJNO- OBRAZOVNOM PROCESU}

Mjera uključivanja pomoćnika ili mentora u odgojno-obrazovni proces u sustav ranog i predškolskog odgoja i obrazovanja, za razliku od školskog odgojno-obrazovnog sustava, a o čemu će biti riječi u drugom dijelu analize, manje je zakonski definirana. Naime, krovni dokumenti koji čine zakonski okvir sustava ranog i predškolskog odgoja i obrazovanja (Državni pedagoški standard predškolskog odgoja i naobrazbe, 2008; Pravilnik o posebnim uvjetima i mjerilima ostvarivanja programa predškolskog odgoja, 1997; Zakon o predškolskom odgoju i obrazovanju, 1997, 2007, 2013, 2019) spominju mogućnost takve vrste podrške djeci s posebnim potrebama, ali o reguliranosti te mjere ne može se govoriti zbog nedovoljne definiranosti uključivanja pomoćnika ili mentora u odgojno-obrazovni proces, propisanosti tko može biti mentor ili pomoćnik, načina njihova osposobljavanja te obavljanja poslova. Pravilnik o pomoćnicima u nastavi i stručnim komunikacijskim posrednicima (2018) pak regulira načine uključivanja i sadržaje obavljanja poslova pomoćnika u nastavi i stručnih komunikacijskih posrednika i to u školama, ali i drugim javnim ustanovama koje 
provode djelatnost odgoja i obrazovanja. Na temelju takvog tumačenja moglo bi se pomisliti kako su i ustanove u području ranog i predškolskog odgoja i obrazovanja, odnosno dječji vrtići, ustanove takve kategorije. Međutim, pri opisivanju postupka ostvarivanja prava na potporu pomoćnika u nastavi, vidljivo je kako spomenuti pravilnik nije namijenjen djeci u dječjim vrtićima jer se postupak pokreće na prijedlog stručnog povjerenstva osnovne škole ili nastavničkog vijeća srednje škole koju učenik pohađa (Pravilnik o pomoćnicima u nastavi i stručnim komunikacijskim posrednicima, 2018). Zakonski akt koji navodi mjeru uključivanja pomoćnika u odgojno-obrazovni proces jest Državni pedagoški standard predškolskog odgoja i naobrazbe (2008). Naime, njime se propisuje da u odgojno-obrazovnoj skupini, ako je u nju uključeno dijete s težim teškoćama, prema procjeni stručnog tima može raditi još jedan odgajatelj ili stručnjak edukacijsko-rehabilitacijskog profila (2008). To bi se svakako moglo smatrati mjerom uključivanja pomoćnika u odgojno-obrazovni proces. Osim toga, Državni pedagoški standard predškolskog odgoja i naobrazbe (2008) propisuje kako se u odgojno-obrazovnu skupinu s posebnim programom za djecu s teškoćama mora, između ostalog, uključiti i pomoćni radnik za njegu, skrb i pratnju.

Što se tiče darovite djece u sustavu ranog i predškolskog odgoja i obrazovanja, u Državnom se pedagoškom standardu predškolskog odgoja i naobrazbe (2008) vrlo šturo navodi mogućnost individualnog mentorskog rada za darovitu djecu. Takav je rad u Državnom pedagoškom standardu predškolskog odgoja i naobrazbe (2008) klasificiran kao poseban program predškolskog odgoja i naobrazbe za darovitu djecu, a uz taj oblik rada navode se $i$ igraonice za darovitu djecu sličnih intelektualnih sposobnosti $i$ interesa te programi specifičnih sadržaja za djecu sličnih sposobnosti, interesa i talenata (glazbena, likovna, športska, jezična, kreativna igraonica). S obzirom na to da se individualni mentorski rad svrstava u poseban program, a ne redoviti, pretpostavlja se da darovita djeca u sustavu ranog i predškolskog odgoja i obrazovanja ne ostvaruju to pravo.

Iz analize krovnih dokumenata u području ranog i predškolskog odgoja $i$ obrazovanja može se zaključiti kako se pitanje pomoćnika i mentora u odgojno-obrazovnom procesu nedovoljno pravno regulira. Međutim, veći se naglasak ipak stavlja na djecu s teškoćama u razvoju, odnosno mogućnost uključivanja pomoćnika koji im u odgojno-obrazovnom procesu može pomoći.

Prethodno navedeno pokazuje kako je sustav ranog i predškolskog odgoja i obrazovanja u tom segmentu nedovoljno pravno reguliran zbog čega se postavlja pitanje zašto je to tako, odnosno zašto postoje tolike razlike u vertikali odgojno-obrazovnog sustava, a odgovori se mogu samo nagađati. Jedan od razloga može biti i činjenica da sustav ranog i predškolskog odgoja i obrazovanja nije obvezan i da obveza počinje tek u godini prije polaska djeteta u osnovnu školu (Pravilnik o sadržaju i trajanju programa predškole, 2014). Također, spomenuta analiza pokazuje i kako se sustav ranog i predškolskog odgoja i obrazovanja 
razlikuje od osnovnoškolskog i srednjoškolskog odgojno-obrazovnog sustava, odnosno kako je pitanje pomoćnika ili mentora u sustavu ranog i predškolskog odgoja i obrazovanja puno slabije regulirano u odnosu na osnovnoškolski i srednjoškolski odgojno-obrazovni sustav.

Uvidom u krovni dokument osnovnoškolskog i srednjoškolskog odgojno-obrazovnog sustava, to jest Zakon o odgoju i obrazovanju u osnovnoj i srednjoj školi (2020), iščitava se mogućnost uključivanja pomoćnika u nastavi, koji sami nisu nositelji odgojno-obrazovne i/ili nastavne djelatnosti, u odgojno-obrazovni proces. Pri tome se za način uključivanja te način i sadržaj osposobljavanja pomoćnika upućuje na Pravilnik o pomoćnicima u nastavi i stručnim komunikacijskim posrednicima (2018). Pitanje obrazovanja učenika s teškoćama u razvoju regulirano je, također, posebnim Pravilnikom o osnovnoškolskom i srednjoškolskom odgoju i obrazovanju učenika s teškoćama u razvoju (2015). Naime, pomoćnici u nastavi se, prema potonjem pravilniku, određuju kao provoditelji profesionalne potpore u školovanju učenika (2015). Nadalje, u Državnom pedagoškom standardu osnovnoškolskog sustava odgoja i obrazovanja (2008) navodi se mogućnost osiguravanja pomoćnika u nastavi učenicima koji posjeduju rješenje o primjerenom obliku školovanja, a kojim je, između ostalog, propisana potrebna pomoć u učenju i obavljanju školskih aktivnosti i zadataka. Osim toga, važno je naglasiti kako se u istom tom dokumentu (2008) primjereni oblici školovanja spominju jedino u glavi zakona Odgoja i obrazovanja učenika s teškoćama. S druge strane, u Državnom pedagoškom standardu srednjoškolskog sustava odgoja i obrazovanja (2008) nije predviđeno osiguravanje pomoćnika u nastavi ili mentora ni za jednu skupinu učenika s posebnim odgojno-obrazovnim potrebama. Slijedom navedenog, državnim pedagoškim standardima za osnovne i srednje škole regulirano je isključivo pitanje pomoćnika u nastavi za učenike s teškoćama u razvoju, ali ne i pitanje mentora ili pomoćnika za darovite učenike.

Što se tiče darovitih učenika, u pojmovniku Državnog pedagoškog standarda osnovnoškolskog sustava odgoja i obrazovanja (2008), pod pojmom „učiteljmentor" podrazumijeva se i učitelj osposobljen za rad s potencijalno darovitim učenicima u osnovnoj školi, ali se taj pojam više nigdje u dokumentu ne navodi, pa ni u čl. 32. kojim se regulira Odgoj i obrazovanje darovitih učenika. Pitanje obrazovanja darovitih učenika regulirano je Pravilnikom o osnovnoškolskom obrazovanju darovitih učenika (1991) te Pravilnikom o srednjoškolskom obrazovanju darovitih učenika (1993). Pri tome se u oba pravilnika jedino u sklopu mjera za poticanje darovitih učenika navodi rad s mentorom te obveza škole za osiguravanjem mentora darovitom učeniku. Ipak, zbog nedovoljne definiranosti mjere rada s mentorom koja uključuje informacije o tome tko može biti mentor, na koji način se provodi njegovo osposobljavanje te na koji način isti obavlja svoje poslove, ne može se govoriti o reguliranosti prava na mentora u odgojno-obrazovnom procesu darovitih učenika. U općim odredbama 
Pravilnika o pomoćnicima u nastavi i stručnim komunikacijskim posrednicima (2018), navedeno je da se pomoćnici u nastavi odnose isključivo na učenike $\mathrm{s}$ teškoćama u razvoju. Također, bitno je istaknuti kako se u okviru Zakona o odgoju i obrazovanju u osnovnoj i srednjoj školi (2020) ne spominje mogućnost uključivanja mentora za darovite učenike.

Iz analize krovnih dokumenata $u$ školskom odgojno-obrazovnom sustavu može se zaključiti kako je pitanje pomoćnika u nastavi za učenike s teškoćama vrlo dobro zakonski regulirano, određujući način uključivanja te način i sadržaj osposobljavanja pomoćnika. S druge strane, mjere rada mentora s darovitim učenicima se u pokojim zakonskim aktima spominju, no zbog nedovoljne definiranosti te mjere ne može se u potpunosti govoriti o reguliranosti prava darovitih učenika na mentora u odgojno-obrazovnom procesu.

\section{IP.2 - REGULIRANJE BROJA DJECE U RAZREDNOM ODJELU I ODGOJNO-OBRAZOVNOJ SKUPINI}

Među analiziranim dokumentima u kojima su u području ranog i predškolskog odgoja i obrazovanja regulirana pitanja vezana uz djecu s posebnim potrebama jedino je Državni pedagoški standard predškolskog odgoja i naobrazbe (2008) u kojem je taj kriterij reguliran. Prema tom dokumentu (2008) odmah na početku djeca su s posebnim odgojno-obrazovnim potrebama definirana kao: djeca s teškoćama (dijete $\mathrm{s}$ utvrđenim stupnjem i vrstom teškoće po propisima iz socijalne skrbi, koje je uključeno u redovitu i/ili posebnu odgojnu skupinu u dječjem vrtiću, ili posebnu odgojno-obrazovnu ustanovu) ili darovita djeca (dijete kojem je utvrđena iznadprosječna sposobnost $u$ jednom ili više područja uključeno u programe ranog i predškolskog odgoja i obrazovanja). No, broj djece $u$ odgojno-obrazovnoj skupini u redovitom programu utvrđuje se jedino ovisno o broju uključene djece s teškoćama (Državni pedagoški standard predškolskog odgoja i naobrazbe, 2008). Drugim riječima, u odgojno-obrazovnu se skupinu može uključiti samo jedno dijete s lakšim teškoćama i tada se broj djece u skupini smanjuje za dvoje djece i jedno dijete s većim ili kombiniranim teškoćama, ako je nedostatan broj djece za ustroj odgojne skupine s posebnim programom, i tada se broj djece smanjuje za četvero (Državni pedagoški standard predškolskog odgoja i naobrazbe, 2008). S druge strane, za darovitu djecu nije predviđeno reguliranje ukupnog broja djece u odgojno-obrazovnoj skupini (Državni pedagoški standard predškolskog odgoja i naobrazbe, 2008).

Analizom je utvrđeno kako je mjera reguliranja broja djece s posebnim potrebama u odgojno-obrazovnoj skupini jedna od najbolje propisanih u hrvatskim zakonskim aktima koji određuju područje ranog i predškolskog odgoja i obrazovanja, iako, uređena je samo za podskupinu djece s teškoćama u razvoju. Darovite se djece, pak, ne dotiče. 
Pitanje reguliranja broja učenika u razrednim odjelima bitno se razlikuje po uređenosti i usklađenosti zakonskih akata za osnovne i srednje škole. Za osnovne škole postoje dva dokumenta, oba proizašla iz Zakona o odgoju i obrazovanju u osnovnoj i srednjoj školi (2018), koja se bave tim pitanjem: Državni pedagoški standard osnovnoškolskog sustava odgoja i obrazovanja (2008) te, nešto noviji, Pravilnik o broju učenika u redovitom i kombiniranom razrednom odjelu i odgojno-obrazovnoj skupini u osnovnoj školi (2010). Oba navedena dokumenta donose mjerila za broj učenika ovisno o tome je li riječ o redovitom razrednom odjelu, kombiniranom razrednom odjelu ili odgojno-obrazovnoj skupini. Državni pedagoški standard osnovnoškolskog sustava odgoja i obrazovanja (2008) propisuje da u razredni odjel mogu biti uključena najviše tri učenika s teškoćama, a u tom slučaju broj učenika može iznositi najviše 20. Također, u tom se dokumentu navodi i da se broj učenika razrednog odjela smanjuje za dva učenika po uključenju jednog učenika s ostalim odgojno-obrazovnim potrebama (2008). Tim je stavkom na taj način naglašeno da se radi o ostalim posebnim potrebama, a koje nisu teškoće, pa se može zaključiti da je riječ o darovitim učenicima. Naime, Državnim pedagoškim standardom osnovnoškolskog sustava odgoja i obrazovanja (2008) učenik s posebnim odgojno-obrazovnim potrebama definiran je kao učenik s teškoćama ili potencijalno darovit učenik. Međutim, u njemu (Državni pedagoški standard osnovnoškolskog sustava odgoja i obrazovanja, 2008) nije definirano koliko maksimalno učenika može sadržavati razredni odjel u koji su uključeni daroviti učenici. Kombinirani razredni odjeli skupine su učenika sastavljene od dva, tri ili četiri razreda, a uobičajeni su u školama s manjim brojem učenika te za učenike od prvog do četvrtog razreda. Za njih je u Državnom pedagoškom standardu osnovnoškolskog sustava odgoja i obrazovanja (2008) reguliran broj učenika ovisno o broju razreda, a broj učenika ovisno o broju razreda u koji su uključeni učenici s teškoćama. Broj učenika za kombinirane odjele ovisno o broju razreda te broju uključenih darovitih učenika nije razmatran.

Državni pedagoški standard osnovnoškolskog sustava odgoja i obrazovanja (2008) razlikuje odgojno-obrazovne skupine ovisno o namjeri njihova ustrojavanja, a njime je propisano da je dodatna nastava individualizirani oblik rada s potencijalno darovitim učenicima i reguliran je njezin broj. Reguliranje broja učenika u razrednim odjelima propisano je još i ranije spomenutim Pravilnikom o broju učenika u redovitom i kombiniranom razrednom odjelu i odgojnoobrazovnoj skupini u osnovnoj školi (2010). Analizirajući ta dva dokumenta, može se zaključiti da je Pravilnik o broju učenika u redovitom i kombiniranom razrednom odjelu i odgojno-obrazovnoj skupini u osnovnoj školi (2010) vrlo konzistentan i usklađen s Državnim pedagoškim standardom osnovnoškolskog sustava odgoja i obrazovanja (2008) po pitanju broja učenika s teškoćama, naglašavajući detaljnu razradu o reguliranju broja učenika. Primjerice, pravilnikom (2010) je precizno definirano kako se broj učenika redovitog i 
kombiniranog razrednog odjela smanjuje ovisno o broju uključenih učenika $\mathrm{s}$ različitim vrstama teškoća te kako se broj učenika s teškoćama ne smanjuje ukoliko neki od učenika ima pomoćnika u nastavi. S druge strane, o usklađenosti ta dva dokumenta ne može se govoriti kada je riječ o regulaciji broja učenika razrednih odjela u koji su uključeni daroviti učenici. Čak štoviše, u Pravilniku (2010) se ne spominje uključivanje darovitih učenika u razredne i kombinirane odjele te, ovisno o tome, regulacija broja učenika. Pravilnikom (2010) je regulirano jedino pitanje broja učenika odgojno-obrazovne skupine dodatne nastave za koju se može reći da se odnosi na darovite učenike (sukladno njezinoj definiciji iz Državnog pedagoškog standarda osnovnoškolskog sustava odgoja i obrazovanja), pri čemu je broj učenika koji je uključen u tu skupinu povećan u odnosu na Državni pedagoški standard osnovnoškolskog sustava odgoja i obrazovanja te iznosi deset. Također, treba imati u vidu i Pravilnik o osnovnoškolskom odgoju i obrazovanju darovitih učenika (1991) koji navodi da broj darovitih učenika u odgojno-obrazovnoj skupini može biti najviše pet, dok je u Državnom pedagoškom standardu osnovnoškolskog sustava odgoja i obrazovanja (2008) taj broj osam, odnosno prema Pravilniku o broju učenika u redovitom i kombiniranom razrednom odjelu i odgojno-obrazovnoj skupini u osnovnoj školi (2010) deset učenika.

Zaključno, pitanje reguliranosti broja učenika u redovitim i kombiniranim razrednim odjelima $u$ osnovnim školama uređeno je za učenike s teškoćama u razvoju, ali ne i darovite učenike. Uspoređujući uređenost reguliranja broja učenika s teškoćama u razvoju i darovitih učenika, može se zaključiti da je ono uređenije za učenike s teškoćama u razvoju.

Pitanjem reguliranosti broja učenika u razrednim odjelima srednjih škola bavi se isključivo Državni pedagoški standard srednjoškolskog sustava odgoja i obrazovanja (2008). U njemu se predviđa reguliranje broja učenika u razrednom odjelu te reguliranje broja učenika ovisno o broju učenika s teškoćama (2008). Također, navodi se i da se broj učenika razrednog odjela u kojem se nalazi darovit učenik uređuje na isti način kao i kada su u pitanju učenici s teškoćama. Međutim, ono što je izostalo jest pitanje uređenja razrednog odjela u kojem se nalaze i daroviti i učenici s teškoćama u razvoju istodobno. Državnim pedagoškim standardom srednjoškolskog sustava odgoja i obrazovanja (2008) propisano je i da se obrazovanje darovitih učenika provodi i u različitim grupama čiji broj nije reguliran, dok je broj uključene darovite djece u obrazovnoj grupi reguliran Pravilnikom o srednjoškolskom obrazovanju darovitih učenika (1993) i on iznosi najviše pet.

Pitanje reguliranosti broja učenika s posebnim odgojno-obrazovnim potrebama u obzir uzima obje podskupine učenika, no značajno je bolje regulirano za učenike s teškoćama u odnosu na darovite učenike. 
Vertikalnom usporedbom dva podsustava odgoja obrazovanja može se reći da su po tom pitanju osnovnoškolski i srednjoškolski sustav bolje regulirani od ranog i predškolskog sustava odgoja i obrazovanja.

\section{IP.3 - DODATAK NA PLAĆU PREMA TEMELJNOM KOLEKTIVNOM UGOVORU (TKU)}

Zakonski akti koji reguliraju pitanje ostvarivanje dodatka na osnovnu plaću različiti su kolektivni ugovori u području ranog i predškolskog te školskog odgojno-obrazovnog sustava.

Kolektivni ugovor za zaposlenike u osnovnoškolskom i srednjoškolskom odgojno-obrazovnom sustavu potpisuju Vlada Republike Hrvatske i sindikati zaduženi za navedene sustave, dok za područje ranog i predškolskog odgoja i obrazovanja ugovor potpisuju sindikati i osnivači dječjih vrtića (MZO, https://mzo. gov.hr/o-ministarstvu/kutak-za-djelatnike-u-znanosti-i-obrazovanju-1719/ kolektivni-ugovori/rani-predskolski-odgoj-i-obrazovanje/978).

Iz navedenog je, dakle, vidljivo kako se jedino za sustav ranog i predškolskog odgoja i obrazovanja ne navodi cjeloviti tekst kolektivnog ugovora, već to pitanje regulira svaki osnivač zasebno. Ukratko, to bi značilo kako svaki osnivač dječjih vrtića ima svoj kolektivni ugovor. Detaljna analiza svih kolektivnih ugovora u području ranog i predškolskog odgoja i obrazovanja daleko premašuje opseg ove analize. Stoga su za potrebe ovog rada analizirani samo neki kolektivni ugovori sa zaposlenicima u predškolskim ustanovama. Cilj analize tih nekoliko kolektivnih ugovora jest pokazati na koji se način dodatci na osnovnu plaću reguliraju te koje druge povlastice, na temelju dodatnog angažmana u radu s djecom s posebnim potrebama, zaposlenici ostvaruju. Prema tome, analizirani su sljedeći kolektivni ugovori:

- Kolektivni ugovor za zaposlene u predškolskim ustanovama grada Zagreba (2015);

- Kolektivni ugovor za zaposlene u Dječjem vrtiću Rijeka (2017);

- Kolektivni ugovor za djelatnost predškolskog odgoja i obrazovanja za radnike zaposlene u Dječjem vrtiću «Maslačak» Đurđevac (2017)

- Kolektivni ugovor za radnike u Dječjem vrtiću Radost i Dječjem vrtiću Sunce (2018).

Analiza navedenih kolektivnih ugovora pokazuje kako samo jedan kolektivni ugovor (Kolektivni ugovor za radnike u Dječjem vrtiću Radost i Dječjem vrtiću Sunce, 2018) rad na poslovima s otežanim ili posebnim uvjetima rada vrednuje s nekoliko dana godišnjeg odmora, a plaću radnika uvećava za rad s djecom s razvojnim i zdravstvenim teškoćama i rad s identificiranom darovitom djecom ( $3 \%$ ) te za rad s djecom s lakšim razvojnim i zdravstvenim teškoćama (2\%). Međutim, ostaje nerazjašnjen rad u posebnim i otežanim uvjetima, odnosno postavlja se pitanje pripadaju li u tu kategoriju odgajatelji koji rade s 
djecom s posebnim potrebama. Za usporedbu, Kolektivni ugovor za zaposlene u predškolskim ustanovama grada Zagreba (2015) određuje kako zaposlenici dječjih vrtića imaju pravo na dodatne dane godišnjeg odmora s obzirom na uvjete rada i to prema kriteriju: poslovi obavljanje kojih je vezano uz buku, neujednačenu temperaturu, vlagu i sl. (spremačica, pralja, švelja, kuharice, ekonom, vozač, domar).

Osim toga, tim se ugovorom (2015) predviđa i honoriranje rada prema ocjeni ravnatelja (1 -3 dana godišnjeg odmora), što može biti prostor za nagrađivanje odgajatelja koji rade $\mathrm{s}$ djecom s posebnim potrebama, barem u vremenu dok se kategorija rada $\mathrm{s}$ djecom $\mathrm{s}$ posebnim potrebama ne uvrsti kao zasebna $\mathrm{u}$ zakonski okvir.

Ono što se iz navedene analize može zaključiti jest kako u području ranog i predškolskog odgoja i obrazovanja, a vezano za honoriranje (dodatci na osnovnu plaće i dodatni dani godišnjeg odmora) rada s djecom s posebnim potrebama, ne postoji pravna i zakonska usklađenost zakonskih akata. Primjera radi, samo jedan od četiri analizirana kolektivna ugovora odskače u pozitivnom smjeru honoriranja toga rada te se rad zaposlenika vrednuje prema vrlo detaljnim kategorijama, od kojih neke izuzetno važne poput te koju opisujemo izostaju.

Kolektivnim ugovorom za zaposlenike u osnovnoškolskim ustanovama (2018) utvrđuju se prava i obveze potpisnika (Vlada RH i ovlašteni sindikat učitelja). Trećom glavom Ugovora uređeno je pitanje plaća i naknada zaposlenika osnovnoškolskih ustanova. Pri tome se navodi pravo na ostvarivanje dodataka na osnovnu plaću u vidu stimulacija, dodataka za posebne uvjete rada, položajnih dodataka te uvećanja plaća. Također, definirani su i Posebni uvjeti rada učitelja koji, između ostalog, predviđaju rad u redovitom ili kombiniranom razrednom odjelu s učenicima s teškoćama u razvoju, ali ne i s darovitim učenicima. Sukladno tomu, definira se dodatak na osnovnu plaću za rad u posebnim uvjetima, ali samo za rad s učenicima s teškoćama u razvoju, ne i darovitim učenicima.

Analogno, Kolektivnim ugovorom za zaposlenike u srednjoškolskim ustanovama (2018) utvrđuju se prava i obveze potpisnika (Vlada RH i ovlašteni sindikat nastavnika).

Trećom glavom Ugovora uređeno je pitanje plaća i naknada zaposlenika srednjoškolskih ustanova. Pri tome, propisani su mogući dodatci na osnovnu plaću za uspješnost u radu, dodatci za otežane uvjete rada, dodatci za posebne uvjete rada, položajni dodatci i uvećanja plaća. U okviru posebnih uvjeta rada, uključen je i rad s učenicima s teškoćama u razvoju te se sukladno vrsti razrednog odjela te programu propisuje određeni dodatak na plaću. Osim što se iz prethodnog članka može iščitati da rad s darovitim učenicima ne pretpostavlja posebne uvjete rada, člankom 23. ovog Ugovora (2018) implicitno je navedeno da se rad s darovitim učenicima planira godišnjim planom i programom rada 
srednjoškolske ustanove te školskim kurikulumom, čime se ne ostvaruje dodatak na plaću nego ga se vrednuje kao rad u dodatnoj nastavi.

Analizom se utvrdilo kako je mjera ostvarivanja dodatka na osnovnu plaću u školskom sustavu bolje regulirana za učitelje koji rade s učenicima s teškoćama u razvoju, nego za one koji rade s darovitim učenicima. Pri tome, srednjoškolski sustav odskače u pozitivnom smjeru jer ipak na neki način predviđa vrednovanje rada učitelja s darovitim učenicima.

\section{IP.4 - AŽURIRANJE ZAKONSKIH AKATA}

U području ranog i predškolskog odgoja i obrazovanja najviše izmjena imao je Zakon o predškolskom odgoju i obrazovanju (1997) koji se, od kada je prvi puta donesen, mijenjao tri puta $(2007 ; 2013 ; 2019)$. Spomenute promjene se, nažalost, gotovo uopće nisu sadržajno odnosile na djecu s posebnim odgojno-obrazovnim potrebama. Nadalje, izmjene Zakona o predškolskom odgoju i obrazovanju reguliraju korištenje suvremene terminologije pa se tako odgoj i naobrazba zamjenjuje -odgojem i obrazovanjem (2013), predškolski odgoj i obrazovanje -ranim i predškolskim odgojem i obrazovanjem (2013), a termin djeca s posebnim potrebama uvodi se kao krovni pojam za djecu s teškoćama u razvoju i darovitu djecu (2007).

Izmjena zakona iz 2013. godine (Odluka o proglašenju zakona o izmjenama i dopunama Zakona o predškolskom odgoju i naobrazbi, 2013) osim terminologije donosi i neke sadržajnije izmjene, no ne vezano za djecu s posebnim potrebama, stoga se u ovom radu neće detaljnije opisivati. Drugi krovni dokument u ovom području, Državni pedagoški standard predškolskog odgoja i naobrazbe (2008), mijenjao se samo jednom i to prije punih deset godina.

Ta se promjena većinom odnosi na koeficijente izvodljivosti, odnosno vremenski rok u kojem je potrebno primijeniti određene odredbe koje Državni pedagoški standard predškolskog odgoja i naobrazbe propisuje (2010). Posebno su zanimljive prilagodbe u pogledu broja djece u odgojno-obrazovnoj skupini pri čemu se koeficijent izvodljivosti pomaknuo s jedan na dva, odnosno s obvezom postizanja u roku od pet godina (a ne tri kao što je to bilo ranije) (2010). Taj je koeficijent izvodljivosti vezan za broj djece u odgojno-obrazovnoj skupini koji, osim o kronološkoj dobi, ovisi i o broju djece s teškoćama koja su u nju uključena, odnosno regulira se koji se broj djece s lakšim, većim ili kombiniranim teškoćama može upisati u odgojno-obrazovne skupine $u$ redovitom programu (2010). Drugim riječima, Državni pedagoški standard predškolskog odgoja i naobrazbe (2010) tom izmjenom propisuje kako dječji vrtići za primjenu imaju još dvije dodatne godine. Stoga, bilo bi dobro informativno proučiti što se od tih prilagodbi uspjelo postići i kakvo je stanje zaista u dječjim vrtićima, posebice po pitanju uključivanja djece s teškoćama u razvoju u redovite odgojno-obrazovne programe. 
Zaključno, jedina izmjena Državnog pedagoškog standarda predškolskog odgoja i naobrazbe seže još u 2010. godinu i ona se odnosi na odgađanje primjene standarda, a ne na kvalitativnu promjenu u području rada s djecom s posebnim odgojno-obrazovnim potrebama.

Osim Zakona o predškolskom odgoju i obrazovanju (1997) i Državnog pedagoškog standarda predškolskog odgoja i naobrazbe (2008), analizirana su i dva pravilnika koja određuju područje djece s posebnim potrebama u području ranog i predškolskog odgoja i obrazovanja, a koji se 20 -ak godina uopće nisu mijenjali. Jedan od njih propisuje obaveznu pedagošku dokumentaciju koja se o djeci mora voditi u dječjem vrtiću (Pravilnik o obrascima i sadržaju pedagoške dokumentacije i evidencije o djeci u dječjem vrtiću, 2001).

Ukratko rečeno, odgajatelji te pedagozi, psiholozi, defektolozi i medicinske sestre moraju voditi dosje djeteta i to za svako dijete koje ima posebnu potrebu (djeca s teškoćama u razvoju i darovita djeca) (2001). Drugi pravilnik koji je analiziran Pravilnik je o posebnim uvjetima i mjerilima ostvarivanja programa predškolskog odgoja (1997) koji propisuje na koji se način mogu ostvarivati programi predškolskog odgoja ukoliko se ne odvijaju u dječjim vrtićima. Između ostaloga, Pravilnik (1997) propisuje kako se pri posebnim ustanovama koje provode osnovnoškolski odgoj i obrazovanje djece s posebnim potrebama, $\mathrm{s}$ teškoćama u razvoju, mogu ostvarivati programi predškolskog odgoja djece s teškoćama u razvoju. Iz tog je vidljivo kako Pravilnik (1997) pod pojmom djeca s posebnim potrebama podrazumijeva samo djecu s teškoćama u razvoju, što je dio zastarjele terminologije i nije u skladu s kriterijem suvremenosti zakonskih akata koji je bio temelj ove analize.

Iz analize krovnih dokumenata u ranom i predškolskom odgojno-obrazovnom sustavu može se zaključiti kako se zakonski akti nisu previše mijenjali, a promjene koje se i jesu dogodile, odnose se na terminologiju i/ili odgađanje primjene standarda, a ne na kvalitativnu promjenu u području rada s djecom $s$ posebnim odgojno-obrazovnim potrebama.

U području osnovnoškolskog odgoja i obrazovanja najviše izmjena, čak 14 (NN, 87/08; 86/09; 92/10; 105/10; 90/11; 5/12; 16/12; 86/12; 126/12; 94/13; 1 $52 / 14 ; 07 / 17 ; 68 / 18 ; 98 / 19 ; 64 / 20)$, imao je trenutno važeći Zakon o odgoju i obrazovanju u osnovnoj i srednjoj školi (2020) koji je prvi put donesen 2008. godine. Važno je napomenuti da su donošenjem tog zakona 2008. godine prestali vrijediti Zakon o osnovnom školstvu (NN, 59/90; 26/93; 27/93; 29/94; $7 / 96 ; 59 / 01 ; 114 / 01 ; 76 / 05)$ te Zakon o srednjem školstvu (NN, 19/92; 26/93; $27 / 93$; 50/95; 59/01; 114/01; 81/05) koji su se još zasebno prvotno mijenjali osam, odnosno sedam puta. Od osam puta koliko je bio mijenjan Zakon o osnovnom školstvu (1990), tek se jedna izmjena Zakona (NN, 59/01) djelomično odnosila na učenike s posebnim odgojno-obrazovnim potrebama i to u dijelu u kojem je definirano da osnivači škola trebaju osigurati sredstva koja iziskuju programi, nastavna sredstva i pomagala i sl. za rad s darovitim učenicima te 
učenicima s teškoćama u razvoju. Isto tako, od sedam izmjena Zakona o srednjem školstvu (1992) samo se jedna izmjena odnosila na učenike s posebnim odgojno-obrazovnim potrebama, tj. samo na učenike $s$ teškoćama u razvoju. Zakon o izmjenama i dopunama Zakona o srednjem školstvu (2005) zapravo proširuje postojeći 22. članak Zakona navodeći da su nastavnici ti koji izrađuju prilagođene programe u skladu sa sposobnostima učenika s teškoćama u razvoju ili na temelju redovitih programa prilagođavaju metode rada. Tom izmjenom reguliraju se još i postupci te uvjeti upisa učenika s teškoćama u razvoju u srednje škole. Opsežnije i sadržajno značajnije promjene vezane za učenike s posebnim odgojno-obrazovnim potrebama dogodile su se donošenjem Zakona o odgoju i obrazovanju u osnovnoj i srednjoj školi (2008). Neke su od promjena sljedeće:

- uveden pojam učenika s posebnim odgojno-obrazovnim potrebama koji obuhvaća darovite učenike te učenike s teškoćama;

- odluka da programe za darovite učenike kao i načine praćenja, školovanja, poticanja, propisuje ministar, a da ih škola provodi te sukladno potrebama organizira dodatni rad;

- pravo darovitih učenika na akceleraciju te završetak školovanja u kraćem vremenu od propisanog (regulirano i pravilnicima za obrazovanje darovitih učenika iz 1991.);

- kategorizaciju učenika s teškoćama prema vrsti teškoća;

- odluka da programe za učenike s teškoćama propisuje ministar;

- reguliranje prava učenika $\mathrm{s}$ teškoćama na primjerene programe školovanja i oblike pomoći;

- mogućnost zaposlenja radnika u školskoj ustanovi koji ispunjavaju posebne potrebe $u$ odgojno-obrazovnom radu, $t j$. rad $s$ učenicima $s$ teškoćama, rad s darovitim učenicima, rad s učenicima - pripadnicima nacionalnih manjina ili u drugim specifičnim uvjetima, a u neposrednom vodstvu nastavnika te njihovu dužnost za stjecanjem temeljnih kompetencija za obavljanje odgojno-obrazovne djelatnosti (današnji pomoćnici u nastavi);

- mogućnost ustrojavanja posebnog razrednog odjela za učenike s teškoćama (ne i darovite) te mogućnost organiziranja razredne nastave za učenike s teškoćama od petog do osmog razreda osnovne škole;

- obveza osiguravanja pratnje na nastavnim izletima, ekskurzijama i sličnim aktivnostima;

- ovisno o vrsti teškoće učenika mogućnost opisnog ili brojčanog ocjenjivanja;

- poseban sadržaj i oblik pedagoške dokumentacije učenika s teškoćama (svjedodžbe, potvrde, uvjerenja, učeničke knjižice, evidencija).

Otada, Zakon se mijenja čak 14 puta, no tim promjenama odgoj i obrazovanje učenika s posebnim odgojno-obrazovnim potrebama bilo je obuhvaćeno 
svega u pet navrata. Prva izmjena Zakona koja se na tu skupinu odnosila bila je o mogućnosti odgode upisa u prvi razred osnovne škole učenika s višestrukim teškoćama (2011), a izmjenom u 2012. godini definirano je samo gdje i kako roditelji trebaju zatražiti takvu odgodu. Veće promjene donesene su 2014. godine kada je odlučeno da mreža školskih ustanova obvezno mora sadržavati programe za učenike s teškoćama (no, ne i programe za darovite učenike) te da školska ustanova može zaposliti radnike za rad s učenicima s teškoćama (dakle, isključivo određenom skupinom učenika s teškoćama, ne i s darovitima), a koji se nazivaju pomoćnici u nastavi ili stručno komunikacijski posrednici, a koji nisu samostalni nositelji odgojno-obrazovne i/ili nastavne djelatnosti. Izmjenom Zakona 2017. godine definira se postupak ostvarivanja prava na pomoćnike u nastavi te regulira način njihovog osposobljavanja. Konačno, posljednja izmjena dogodila se 2018. godine kada je donesena odluka da učenici s višestrukim teškoćama imaju pravo završetka osnovne škole do 21 . godine života te su u mrežu školskih ustanova uvršteni i programi za darovite učenike. Iz navedenog može se uočiti kako je potreba osiguravanja pomoćnika u nastavi za učenike s posebnim odgojno-obrazovnim potrebama postojala već 2008. godine, dok su se 2014. godine pomoćnici u nastavi ograničili samo na učenike s teškoćama. Prvi pravilnik o pomoćnicima u nastavi donesen je tek deset godina kasnije. Također, bitno je istaknuti da su gotovo sve izmjene bile vezane uz odgoj i obrazovanje učenika s teškoćama. Preciznije, od sveukupno devet izmjena koje su se odnosile na učenike s posebnim odgojno-obrazovnim potrebama, samo su se dvije odnosile na darovite učenike, dok njih osam na učenike s teškoćama u razvoju.

Sljedeći važni dokumenti državni su pedagoški standardi za osnovne i srednje škole doneseni 2008. godine koji se otada nisu mijenjali. Iako je stupanje na snagu pojedinih članaka predviđeno sve do 2022. godine, te se u skladu s time možda mogu očekivati značajnije promjene, bitno je naglasiti da su oni standardi koji se odnose na odgoj i obrazovanje djece s posebnim odgojno-obrazovnim potrebama označeni s koeficijentom izvodljivosti standarda 0 , što znači da su svi predviđeni standardi mogli stupiti na snagu odmah po donošenju, točnije 2008. godine. Sukladno tomu, ti standardi mogli su podleći promjenama, što implicira da se jednom doneseni standardi 12 godina nisu mijenjali neovisno o novim saznanjima u odgoju i obrazovanju te skupine učenika.

Jedina verzija Pravilnika o pomoćnicima u nastavi i stručnim komunikacijskim posrednicima donesena je relativno nedavno, 2018. godine. Taj je podatak iznenađujući s obzirom na to da niz dokumenata, od Državnog pedagoškog standarda srednjoškolskog sustava odgoja i obrazovanja (2008), Državnog pedagoškog standarda srednjoškolskog sustava odgoja i obrazovanja (2008) te Pravilnika o osnovnoškolskom i srednjoškolskom odgoju i obrazovanju učenika s teškoćama u razvoju (2015), izrijekom ističu pravo učenika s teškoćama u razvoju na pomoćnika u nastavi. Nadalje, čak i pravilnici o odgoju i 
obrazovanju darovitih učenika $(1991 ; 1992)$ navode pravo na rad s mentorom. Budući da su pomoćnici i mentori u nastavi predviđeni za rad s učenicima s posebnim odgojno-obrazovnim potrebama, a pravilnik o njima donesen deset ili više godina kasnije, postavlja se pitanje o (ne)ažurnosti institucija kada je riječ o usklađivanju i pravovremenom donošenju potrebnih zakonskih akata vezanih uz odgoj i obrazovanje učenika s posebnim odgojno-obrazovnim potrebama. Dodatno, donošenje takva pravilnika samo za jednu podskupinu učenika s posebnim potrebama opetovano ukazuje na zanemarivanje i nedovoljno reguliranje odgoja i obrazovanja darovitih učenika. Osim toga, još se jednom ističe i problem nedovoljnog reguliranja zakonskog okvira u području ranog i predškolskog odgoja i obrazovanja u kojem pravilnik koji bi regulirao pitanje pomoćnika u odgojno-obrazovnom procesu niti ne postoji.

Prva verzija trenutno važećeg Pravilnika o broju učenika u redovitom i kombiniranom razrednom odjelu i odgojno-obrazovnoj skupini u osnovnoj školi (2009) donesena je 1991. godine, kada taj pravilnik nije uopće regulirao broj učenika razrednog odjela u odnosu na učenike s posebnim odgojno-obrazovnim potrebama. Učenici se s teškoćama u razvoju ne spominju, a iako se predviđa rad s dodatnom grupom učenika koja u pravilu iznosi od osam do deset učenika, ne može se sa sigurnošću tvrditi da se to odnosilo na grupe darovitih učenika. Godine 1996. ne mijenja se ništa značajno vezano za regulaciju broja učenika s posebnim potrebama, a prvi se put učenici s teškoćama u tom Pravilniku (2009) spominju izmjenom 1999. godine. Tada se broj učenika u redovitom i kombiniranom odjelu regulirao sukladno broju integriranih učenika s teškoćama i ovisno o vrsti teškoća. S druge strane, daroviti se učenici kao takvi ne spominju, no također se prvi put pojavljuje odgojno-obrazovna skupina, ne vežući se usko uz darovite učenike, za koju je predviđen maksimalan broj od 10 učenika (Pravilnik o broju učenika u redovitom i kombiniranom razrednom odjelu i odgojno-obrazovnoj skupini u osnovnoj školi, 2009).

Nadalje, najnovijom izmjenom pravilnika iz 2009. godine, reguliranje broja učenika uključenih u redovite i kombinirane razredne odjele te odgojno-obrazovne skupine detaljno je razrađeno, a prvi put bi se svrha ustrojenja odgojno-obrazovne skupine mogla povezati s radom s darovitim učenicima, ali samo u okviru dodatne nastave, ne i redovitog ili kombiniranog razrednog odjela.

Taj nedostatak, između ostalog, ukazuje na potrebno osuvremenjivanje gore navedenog 12 godina starog Pravilnika. Također, otvorenim ostaju pitanja zašto takav pravilnik ne postoji i za srednje škole ili zašto se u postojeći ne ugrade dodatne odredbe za srednje škole, ali i hoće li se to dogoditi potrebnom novom izmjenom postojećeg pravilnika (2009).

Stupanjem na snagu Pravilnika o osnovnoškolskom i srednjoškolskom odgoju i obrazovanju učenika s teškoćama u razvoju (2015) prestali su važiti Pravilnik o osnovnoškolskom odgoju i obrazovanju učenika s teškoćama u razvoju (1991) te Pravilnik o srednjoškolskom obrazovanju učenika s teškoćama 
i većim teškoćama u razvoju (1992), što je zapravo i jedina izmjena tog pravilnika koji se bavi učenicima s teškoćama u razvoju. Ipak, analizom se utvrđuje da se pravilnici u bitnom razlikuju u smislu razvijenije i suvremenije programske i profesionalne potpore, orijentacijske liste s vrstama teškoća, ustrojstva razrednih odjela i programa itd., a u skladu sa znanstvenim i pedagoško-psihološkim spoznajama. Ono što je i tim Pravilnikom (2015) ostalo djelomično zanemareno i nedovoljno razrađeno jest pedagoško-didaktička prilagodba potrebna učenicima.

Nasuprot tomu, pravilnici vezani za odgoj i obrazovanje učenika osnovnih i srednjih škola nakon što su doneseni nisu prošli niti jednu izmjenu ni dopunu (Pravilnik o osnovnoškolskom obrazovanju darovitih učenika, 1991; Pravilnik o srednjoškolskom obrazovanju darovitih učenika, 1993).

Stoga, moglo bi se reći da je fokus i interes obrazovne politike više usmjeren na samo jednu podskupinu učenika s posebnim odgojno-obrazovnim potrebama, a to su učenici s teškoćama u razvoju. Osim toga, iz provedene analize proizlazi još veći problem, a to je zapostavljanje darovitih učenika uopće. Dok se u svijetu, ali i u Hrvatskoj, posljednjih dvadesetak godina događa ekspanzija zanimanja znanstvene zajednice za istraživanjem područja odgoja i obrazovanja darovite djece i učenika, ali i značajnih dobivenih rezultata, Hrvatska nije pravovremeno odgovorila na suvremene spoznaje te u skladu s time prilagodila odgovarajuće vlastite zakonske akte.

Također, pretpostavlja se da je prethodno uočena neusklađenost dokumenata od terminologije do reguliranja broja djece i učenika s posebnim odgojno-obrazovnim potrebama u okviru razrednih odjela/odgojno-obrazovnih skupina rezultat zastarjelih i neažuriranih zakonskih akata.

Zaključno, i ova je analiza, kao i mnoge opisane gore u radu, pokazala kako se u školskom sustavu ažuriranje zakonskih akata, odnosno njihove izmjene, u većini slučajeva odnose samo na učenike s teškoćama u razvoju, dok su daroviti učenici u odnosu na njih zanemareni. Također, analizom se utvrdilo i kako su se krovni dokumenti u školskom sustavu često mijenjali, brojčano ih je puno te donose neke kvalitativne promjene vezane za odgoj i obrazovanje učenika s posebnim odgojno-obrazovnim potrebama. 


\section{ZAKLJUČAK}

Analizom prvog kriterija, odnosno mjere uključivanja pomoćnika ili mentora u odgojno-obrazovni proces, pokazalo se kako se ona u vertikali odgojno-obrazovnog sustava sveobuhvatnije i konkretnije regulira u školskom odgojno-obrazovnom sustavu. S druge strane, sustav ranog i predškolskog odgoja i obrazovanja, pak, karakterizira nedovoljna reguliranost i zakonska definiranost navedene mjere. Ako se pogledaju samo nazivi pravilnika koji reguliraju to područje, onda je jasno kako pravilnika o pomoćnicima i/ili mentorima u tom sustavu, za razliku od školskog sustava, uopće nema. Što se tiče komparativne analize na horizontalnoj razini, može se zaključiti kako se u oba sustava (školski te rani i predškolski) mjera rada mentora s darovitim učenicima u pokojim zakonskim aktima spominje, no, zbog nedovoljne definiranosti te mjere ne može se govoriti o reguliranosti prava darovitih učenika na mentora u odgojno-obrazovnom procesu. Drugim riječima, analizom se pokazalo kako je mjera uključivanja pomoćnika ili mentora u odgojno-obrazovni proces bolje zakonski regulirana i definirana za djecu s teškoćama u razvoju.

Analizom drugog kriterija utvrdilo se kako je pitanje reguliranosti broja djece i učenika s posebnim odgojno-obrazovnim potrebama najravnopravnije uređeno za srednje škole, najdetaljnije za učenike s teškoćama u razvoju u osnovnoj školi, a najmanje uređeno za djecu s posebnim potrebama u sustavu ranog i predškolskog odgoja i obrazovanja. Horizontalna je analiza, pak, pokazala postojanje razlike $\mathrm{u}$ uređenosti i regulaciji te mjere $\mathrm{u}$ korist djece $\mathrm{s}$ teškoćama u razvoju.

Nadalje, vertikalna komparativna analiza trećeg kriterija, odnosno ostvarivanja dodatka na osnovnu plaću, pokazala je kako je školski sustav, za razliku od ranog i predškolskog, ujednačen te kako svi zaposlenici (osnovnih i srednjih) škola imaju jedan kolektivni ugovor koji regulira njihova prava. S druge strane, horizontalna je analiza tog kriterija pokazala kako je mjera dodatka na osnovu plaće bolje regulirana za učitelje koji rade s učenicima s teškoćama u razvoju, nego za one koji rade s darovitim učenicima. Pri tome, srednjoškolski sustav odskače u pozitivnom smjeru jer predviđa neki oblik honoriranja rada učitelja koji rade s darovitim učenicima.

Konačno, iz analize se može zaključiti kako temeljni akti koji bi sadržajno propisivali područje rada $\mathrm{s}$ djecom s posebnim odgojno-obrazovnim potrebama u području ranog i predškolskog odgoja i obrazovanja zapravo nisu doneseni. Jednostavnije rečeno, pravilnici za djecu s teškoćama u razvoju i darovitu djecu u tom području uopće ne postoje. Zakoni, pravilnici i standardi koji, pak, u području ranog i predškolskog odgoja i obrazovanja postoje općeniti su, minimalno se mijenjaju, i to većinom u pogledu terminologije, te suštinski ili sadržajno ne donose ništa. Za razliku od zakonskih akata u području ranog i predškolskog odgoja i obrazovanja, zakonski akti koji reguliraju 
osnovnoškolski i srednjoškolski odgojno-obrazovni sustav češće su mijenjani, brojčano ih je više, ali i sadržajnije bolje reguliraju problematiku učenika s posebnim odgojno-obrazovnim potrebama. Međutim, treba naglasiti da su se izmjene u većini slučajeva odnosile samo na učenike s teškoćama u razvoju, dok su daroviti učenici ostali zanemareni.

Za kraj ostaje zapitati se na što ukazuju navedeni rezultati i koje su njihove implikacije. U Strategiji obrazovanja, znanosti i tehnologije (2014) raspisani su različiti ciljevi i mjere koji bi se u odgoju i obrazovanju trebali provesti, određeno je tko je za njih nadležan, tko će ih provoditi i koji su pokazatelji provedbe. Ne bi li se odredile najvažnije implikacije rezultata ovog istraživanja, naglasak će se staviti na one mjere koje se odnose na odgoj i obrazovanje djece i učenika s posebnim odgojno-obrazovnim potrebama te na one pokazatelje provedbe koji su s njima povezani, a koji se odnose na promjenu zakonskih akata.

Slijedom navedenoga, implikacije su ovog istraživanja sljedeće:

1. Usvojiti pravilnik koji regulira sve značajne aspekte rada obrazovnih asistenata ili pomoćnika te mentora, i to u cjelovitoj vertikali odgojnoobrazovnog sustava, kako bi se uspostavio pravedan i učinkoviti sustav odobravanja, angažiranja, financiranja, edukacije i licenciranja obrazovnih asistenata (2014).

2. Revidirati pravilnike koji reguliraju odgoj i obrazovanje darovitih učenika tako da se omogući identifikacija, školovanje, poticanje i praćenje darovitih učenika na optimalan način (2014) te osigura vidljivost $i$ te podskupine djece i učenika s posebnim odgojno-obrazovnim potrebama u odgojno-obrazovnom sustavu.

3. Osmisliti odgovarajuća rješenja u propisima koji definiraju normu učitelja, nastavnika (2014) i odgajatelja, ali i honoriranje njihova dodatnog angažmana.

4. Ažurirati zakonske akte u skladu sa suvremenim znanstvenim spoznajama te ujednačiti temeljne kolektivne ugovore za zaposlenike u ranom i predškolskom odgoju i obrazovanju.

Strategija obrazovanja, znanosti i tehnologije (2014) na kraju raspisuje poneke smjernice za njeno provođenje među kojima je i osiguravanje provedbenog okvira, što između ostaloga podrazumijeva izradu analize potreba izmjena postojećih zakonskih akata u svrhu ostvarivanja propisanih ciljeva. Analiza postojećih zakonskih akata u području odgoja i obrazovanja djece i učenika s posebnim odgojno-obrazovnim potrebama može poslužiti u slične svrhe, odnosno u svrhu izmjene postojećih zakonskih akata kako bi (odgoj i) obrazovanje djece i učenika s posebnim odgojno-obrazovnim potrebama bilo kvalitetno i inkluzivno. 


\section{OGRANIČENJA I PREPORUKE ZA DALJNJA ISTRAŽIVANJA}

Jedno od ograničenja ovog istraživanja vezano je uz metodologiju istraživanja. Iako su postavljeni kriteriji analize proizašli iz teorijskih razmatranja i istraživačkih pitanja, postoji još mnogo kriterija po kojima bi se mogla i trebala napraviti kako vertikalna tako i horizontalna analiza zakonske regulative vezane za odgoj i obrazovanje djece s posebnim odgojno-obrazovnim potrebama. Primjerice, neki od potencijalnih kriterija mogle bi biti mjere za prepoznavanje, praćenje, rad i potporu djece i učenika s posebnim odgojno-obrazovnim potrebama te njihova usklađenost sa suvremenim znanstvenim spoznajama. Također, jedna od preporuka za daljnja istraživanja usporedba je zakonskih akata koji to područje reguliraju u Republici Hrvatskoj u odnosu na druge države Europe i/ ili svijeta.

\section{LITERATURA}

Ainscow, M. i Tweddle, D. (2003). Understanding the Changing Role of English Local Education Authorities in Promoting Inclusion. U J. Allan (Ur.) Inclusion, Participation and Democracy: What is the Purpose? (str. 167-177). Kluwer: Academic Publishers.

Booth, T., i Ainscow, M. (2002). Index for Inclusion: Developing Learning and Participation in Schools. Centre for Studies on Inclusive Education (CSIE).

Brajša-Žganec, A., Brkljačić, T., Franc, R., Merkaš, M., Radačić, I., Sučić, I., i Šikić-Mićanović, L. (2014). Analiza stanja prava djece u Hrvatskoj 2014. Ured UNICEF-a za Hrvatsku, Zagreb.

Cerić, H. (2008). Mogućnost konstituiranja teorije inkluzivnog obrazovanja. Metodički obzori: časopis za odgojno-obrazovnu teoriju i praksu, 3(5), 49-62. https://hrcak. srce.hr/25800

Clark, C., Dyson, A., i Millward, A. (2005). Introducing the Issue of Theorising. U C. Clark, A. Dyson, i A. Millward (Ur.), Theorising Special Education (str. 1-6). Taylor \& Francis e-Library.

Cvetković-Lay, J. (2010). Darovito je, što ću sa sobom? Priručnik za obitelj, vrtić i školu. Zagreb: Alinea.

Čudina-Obradović, M. (1991). Nadarenost: razumijevanje, prepoznavanjem razvijanje. Zagreb: Školska knjiga.

Delisle, J.R. (1999). For Gifted Students, Full Inclusion is a Partial Solution. Educational Leadership, 57(3), str. 80-83.

Division for Early Childhood/National Association for the Education of Young Children. (2009). Early Childhood Inclusion: A Joint Position Statement of the Division for Early Childhood (DEC) and the National Association for the Education of Young Children (NAEYC). 
French, L.R. i Shore, B.M. (2008). A Reconsideration of the Widely Held Conviction that Gifted Students Prefer to Work Alone. U T. Balchin (Ur.) The Routledge International Companion to Gifted Education (str. 325-366). London: Routledge.

Igrić, Lj. (2004). Društveni kontekst, posebne potrebe/invaliditet/teškoće u razvoju i edukacijsko uključivanje. Hrvatska revija za rehabilitacijska istraživanja, 40(2), 151-164. https://hrcak.srce.hr/11523

Jablan, B., i Kovačević, J. (2008). Obrazovanje u redovnim školama i školama za decu ometenu u razvoju: zajedno ili paralelno. Nastava $i$ vaspitanje, 57(1), 43-54.

Koren, I. (1989). Kako prepoznati i identificirati nadarenog učenika. Zagreb: Školske novine.

Luketić, D. i Karamatić Brčić, M. (2018). Daroviti učenici u inkluzivnom odgoju I obrazovanju. U I. Radeka (Ur.) Odgoj i obrazovanje darovitih učenika (str. 35-49). Zadar: Sveučilište u Zadru.

Milgram, R. M. (1991). Counseling Gifted and Talented Children. Norwood, NJ: Ablex.

Ministarstvo znanosti i obrazovanja (2021). Rani i predškolski odgoj i obrazovanje. Republika Hrvatska, Ministarstvo znanosti i obrazovanja.

https://mzo.gov.hr/o-ministarstvu/kutak-za-djelatnike-u-znanosti-i-obrazovanju-1719/ kolektivni-ugovori/rani-predskolski-odgoj-i-obrazovanje/978

Mönks, F. i Mason, E. (2000). Developmental Psychology and Giftedness: Theories and Research. U K. Heller, F. Mönks, R. Sternberg, R. Subotnik (Ur.), International Handbook of Giftedness and Talent (str. 141-156). Oxford: Pergamon Press.

OECD, Educational Policies for Pupils at Risk and Pupils with Disabilities in Southeast Europe - Croatia (Obrazovne politike za učenike u riziku i učenike s teškoćama u razvoju u Jugoistočnoj Europi - Hrvatska), izvješće, 2007.sẸp:

Pravobraniteljica za osobe s invaliditetom, Izvješće o radu pravobraniteljice za osobe s invaliditetom za 2013. godinu, Zagreb, Pravobraniteljica za osobe s invaliditetom, 2013.

Pravobraniteljica za osobe s invaliditetom, Izvješće o radu pravobraniteljice za osobe s invaliditetom za 2019. godinu, Zagreb, Pravobraniteljica za osobe s invaliditetom, 2019.

Quinn, G., i Degener, T. (2002). The Moral Authority for Change: Human Rights Values and the Worldwide Process of Disability Reform. U G. Quinn, T. Degener et al (ur.), Human Rights and Disability: The Current Use and Future Potential of United Nations Human Rights Instruments in the Context of Disability (str. 13-28). New York, Geneva: United Nations. https://www.ohchr.org/Documents/ Publications/HRDisabilityen.pdf

Rajović, R. (2009). IQ djeteta - briga roditelja: za predškolski uzrast. Beograd: Dobra knjiga.

Sekulić-Majurec, A. (1995). Darovita djeca i obitelj: istine i zablude. Društvena istraživanja, 4(4-5), str. 552-561. 
Sindik, J. (2013). Konstrukcija upitnika stavova odgojiteljica o inkluziji djece s teškoćama u razvoju u dječje vrtiće. Specijalna edukacija i rehabilitacija, 12(3), 309334. https://doi.org/10.5937/specedreh12-4204

Stubbs, S. (2008). Inclusive Education. Where There are few Resources. The Atlas Alliance.

Sunko, E. (2016). Društveno povijesni kontekst odgoja i obrazovanja djece s teškoćama u razvoju. Školski vjesnik: časopis za pedagogijsku teoriju i praksu, 65(4), 601-620. https://hrcak.srce.hr/178259

Tao, T. i Shi, J. (2018). Enriched Education Promotes the Attentional Performance of Intellectually Gifted Children. High Ability Studies, 29(1), str. 23-35.

Vican, D. (2018). Doživljajna pedagogija u kontekstu odgoja i obrazovanja talentiranih i darovitih učenika. U I. Radeka (Ur.) Odgoj i obrazovanje darovitih učenika (str. 9-33). Zadar: Sveučilište u Zadru.

Vizek Vidović, V., Vlahović - Štetić, V., Rijavec, M. i Miljković, D. (2003). Psihologija obrazovanja. Zagreb: IEP.

Vrkić Dimić, J. i Buterin Mičić, M. (2018). Razvoj darovitosti kroz suradničke oblike učenja. U I. Radeka (Ur.) Odgoj i obrazovanje darovitih učenika (str. 51-67). Zadar: Sveučilište u Zadru.

Winerbrenner, S. (2001). Teaching Gifted Kids in the Regular Classroom: Strategies and Techniques Every Teacher Can Use to Meet the Academic Needs of the Gifted and Talented. Minneapolis: Free Spirit Publishing Inc.

\section{Zakonski akti:}

Državni pedagoški standard predškolskog odgoja i naobrazbe, Narodne novine, 63/08, i 90/10 (2010).

Zakon o predškolskom odgoju i obrazovanju, Narodne novine, 10/97, 107/07, 94/13, i 98/19 (2019).

Pravilnik o posebnim uvjetima i mjerilima ostvarivanja programa predškolskog odgoja, Narodne novine, 133/97 (1997).

Pravilnik o obrascima i sadržaju pedagoške dokumentacije i evidencije o djeci u dječjem vrtiću, Narodne novine, 83/01 (2001).

Pravilnik o sadržaju i trajanju programa predškole, Narodne novine, 107/14 (2014).

Državni pedagoški standard srednjoškolskog sustava odgoja i obrazovanja, Narodne novine, 63/08, i 90/10 (2010).

Državni pedagoški standard osnovnoškolskog sustava odgoja i obrazovanja, Narodne novine, 63/08, i 90/10 (2010).

Pravilnik o srednjoškolskom obrazovanju darovitih učenika, Narodne novine, 90/93 (1993).

Pravilnika o osnovnoškolskom odgoju i obrazovanju učenika s teškoćama u razvoju, Narodne novine, 23/91 (1991).

Pravilnik o osnovnoškolskom i srednjoškolskom odgoju i obrazovanju učenika s teškoćama u razvoju, Narodne novine, 24/15 (2015). 
Kolektivni ugovor za zaposlenike u srednjoškolskim ustanovama, Narodne novine, $51 / 18$ (2018).

Zakon o odgoju i obrazovanju u osnovnoj i srednjoj školi, Narodne novine, 87/08, $86 / 09,92 / 10,105 / 10,90 / 11,86 / 12,16 / 12,94 / 13,152 / 14,7 / 17,68 / 18,98 / 19$, i 64/20 (2020).

Pravilnik o broju učenika u razrednom odjelu u osnovnoj školi, Narodne novine, 61/96 (1996).

Pravilnik o broju učenika u redovitom i kombiniranom razrednom odjelu u osnovnoj školi, Narodne novine, 74/99 (1999).

Pravilnik o broju učenika u redovitom i kombiniranom razrednom odjelu i odgojno-obrazovnoj skupini u osnovnoj školi, Narodne novine, 124/09, i 73/10 (2010).

Pravilnik o pomoćnicima u nastavi i stručnim komunikacijskim posrednicima, Narodne novine, 102/18, 59/19, i 22/20 (2020).

Kolektivni ugovor za zaposlenike u osnovnoškolskim ustanovama, Narodne novine, 51/18 (2018).

Pravilnik o osnovnoškolskom odgoju i obrazovanju darovitih učenika, Narodne novine, 34/91 (1991).

Kolektivni ugovor za zaposlene u predškolskim ustanovama grada Zagreba, Službeni glasnik Grada Zagreba, 18/15 (2015).

Kolektivni ugovor za zaposlene u Dječjem vrtiću Rijeka, Službeno glasilo Grada Rijeke, 12/17 (2017).

Kolektivni ugovor za djelatnost predškolskog odgoja i obrazovanja za radnike zaposlene u Dječjem vrtiću «Maslačak « Đurđevac, Službene novine Grada Đurđevca, 1/17 (2017).

Kolektivni ugovor za radnike u Dječjem vrtiću Radost i Dječjem vrtiću Sunce, Glasnik Grada Zadra, 6/18 (2018). 